\title{
A SHIFTIN TRADITIONAL WISDOM OF SEMENDE TRIBE IN PULAU PANGGUNG TANGGAMUS
}

\author{
Handi Mulyaningsih ${ }^{1}$, Tina Kartika ${ }^{2}$, Hertanto ${ }^{3}$ and Ari Darmastuti ${ }^{4}$ \\ ${ }^{1}$ Departement of Sociology, Universitas Lampung, Indonesia, \\ ${ }^{2}$ Departement of Commucation, Universitas Lampung, Indonesia, \\ ${ }^{3,4}$ Departement of Government Science, Universitas Lampung, Indonesia \\ Jl. Sumantri Brojonegoro No. 1 Gedung Meneng, Bandar Lampung
}

E-mail: handimulyaningsih@fisip.unila.ac.id; tinakartika@fisip.unila.ac.id; hertanto@fisip.unila.ac.id

\begin{abstract}
The traditional wisdom of tunggu tubang has shifted due to economic needs, lack of agricultural land, job mobility, marriage with other than Semende tribe, which impacts the rights fulfilling and obligations of tunggu tubang. However, this shift has been responded to by innovations so that this traditional wisdom persisted. This research is to describe innovations in maintaining the traditional wisdom. This research uses descriptive quantitative method with 40 randomly chosen respondents. Data were taken from interviews using a questionnaire, and interviews with key informants. The data were analyzed quantitatively with frequency tables, given the meaning with the structural functional approach of Talcott Parson, that traditional wisdom still functions when able to adapt, goal attainment, integration, latent maintenance. The results showed: $92.5 \%$ tunggu tubang to get rights to houses, gardens, fields and carrying out their obligations, but $7.5 \%$ without these rights (tepang bangkang) so they cannot carry out their obligations, namely occupying an inheritance house, taking care of their parents and their younger siblings. Tunggu tubang property sold out.This violation is tolerated because of economic necessity. But tepang bangkang still the decision maker in the family and can give the right for the next tunggu tubang. If tunggu tubang married to someone other than Semende tribe, her husband follows it.If working outside the city, rights are still given while obligations are carried out indirectly. This adaptation makes the traditional wisdom survive, be the goal of life, carries out the function of integration, but the function of pattern maintenance is getting weaker.
\end{abstract}

Key words: traditional wisdom; tunggu tubang; shift in value; AGIL

\section{PERGESERAN KEARIFAN TRADISIONAL SUKU SEMENDE DI PULAU PANGGUNG TANGGAMUS}

\begin{abstract}
ABSTRAK. Kearifan tradisional tunggu tubang mengalami pergeseran karena kebutuhan ekonomi, bekurangnya lahan pertanian, mobilitas pekerjaan, perkawinan dengan selain suku Semende, yang berdampak pada pemenuhan hak dan kewajiban tunggu tubang. Namun, pergeseran ini direspon dengan inovasi-inovasi sehingga kearifan tradisional ini tetap bertahan. Penelitian ini untuk mendeskripsikan inovasi-inovasi dalam mempertahankan kearifan tradisioanl tunggu tubang. Penelitian menggunakan metode deskriptif kuantitatif dengan 40 responden yang diambil secara acak. Data diambil melalui wawancara dengan menggunakan questioner, dilengkapi dengan wawancara kepada informan kunci. Data dianalisis secara kuantitatif dengan tabel-tabel frekuensi, diberikan pemaknaan dengan pendekatan struktural fungsional Talcott Parson, bahwa kearifan tradisional tetap berfungsi apabila mampu beradaptasi, memiliki tujuan, terintegrasi, dan memelihara sistem. Hasil penelitian menunjukkan 92,5\% tunggu tubang memperoleh hak atas rumah, kebun, ladang dan menjalankan kewajibannya, namun 7,5\% tanpa hak tersebut (tepang bangkang) sehingga tidak dapat melaksanakan kewajibannya yaitu tinggal di rumah pusaka, tidak mengurusi orang tua dan adik-adiknya. Habisnya harta tunggu tubang karena dijual. Pelanggaran ini ditolelir karena kebutuhan ekonomi. Tetapi tepang bangkang tetap sebagai pengambil keputusan di keluarga dan dapat memberikan hak kepada tunggu tubang berikutnya. Apabila tunggu tubang menikah dengan selain suku Semende, maka suaminya mengikutinya. Apabila bekerja di luar kota, hak tetap diberikan, dan kewajiban dijalankan secara tidak langsung. Adaptasi ini menjadikan kearifan tradisional tetap bertahan, sehingga masyarakat memiliki tujuan, ter integrasi, tetapi fungsi pemeliharaan pola semakin lemah.
\end{abstract}

Kata kunci: kearifan tradisional; tunggu tubang; pergeseran nilai; AGIL

\section{INTRODUCTION}

Traditional wisdom is the values, norms that guide people's behavior in everyday life. Koentjaraningrat (Koentjaraningrat, 1974) explains that traditional wisdom is socialized in a long-term evolutionary manner from generation to generation so that it is internalized in humans. Kluckohn (in
(Mariane, 2014) states that traditional values as well as cultural values are general conceptions that are organized, influencing human behavior related to nature, human position in nature, social interaction, desirable and undesirable things related to nature. with the environment and fellow human beings. In the general conception of cultural values contained five main problems of human life, namely (1) the 
nature of life; (2) the nature of the work; (3) the nature of human position; (4) the nature of human relations with the natural surroundings; and (5) the nature of human relations with each other. Therefore, traditional wisdom has a very important position and role in the sustainability of human life.

Many studies show that traditional wisdom has the ability to deal with foreign cultural influences, as stated (Quaritch Wales, 2001 dalam (Yusuf \& Dewi Anggraini, 2020 : 85); because it becomes a culture identity, an identity/personality that is able to absorb and cultivate foreign cultures (Ayatrohaedi, 2006 : 18-19); Trunyan Culture because Culture Experience, Culture Knowledge, Edukasi dan Regulasi (Aridiantari et al., 2020 : 68). Therefore, local wisdom is a cultural element that must be explored, studied and revitalized. Such as identifying various local potentials that apply across cultures and globally (Sartini, 2004:111); strengthening of the foundation of national identity in facing the challenges of globalization (Moita, 2017) so that society does not change when interacting with global values; make development more effective and efficient because it accelerates the process of adapting values (Oktaviani et al., 2016) so that there is no resistance and conflict in development; including useful in the development of natural tourism and culinary tourism (Widiana \& Wikantiyoso, 2018). Therefore, it is important to recognize local potential (Sartini, 2004). Lontaraq Pappaseng manuscript which contains advice on social ethics can be taught in local content at primary and secondary school learning (Abbas, 2013 : 272). Research ((Vuspitasari \& Ewid, 2020 : 26) shows that Kuma women's local wisdom supports the improvement of the household economy if the government conducts community empowerment based on local wisdom; and technology- based (Amrizal \& Sumadi, 2018 :57). In fact, traditional wisdom has been proven to enable forest communities to take advantage of the forest but still maintain forest sustainability. (Pratiwi, 2016); even strengthen the food security of farming families (Sari \& Zuber, 2020). The results of research (Mulyaningsih, 1997), forests are a place for the Semendo Tribe to depend on for food. To maintain food security, the forest is maintained in order to maintain its fertility with a shifting cultivation pattern, where the forest will be rested so that it is fertile to be managed again. That is why traditional wisdom needs to be socialized to the younger generation (Gadeng et al., 2018).

The problem is that these traditional wisdom values are faced with many factors that make them shift or even disappear. The results of (Hidayati,
2016) research that water was originally abundant so that the value of water which was originally a social dimension is now commercialized. This is due to the disappearance of local institutions and traditional water management institutions, as well as the erosion of the 'sense' of shared ownership of the surrounding water resources. The problem of shifting values is due to the declining function of local wisdom in 'maintaining' a harmonious relationship between society and nature, as well as challenges to the existence of local wisdom, especially those related to population pressure, modernization and development activities that do not pay attention to traditional wisdom. (Wahyuni \& Pinasti, 2018). Similar research on shifting cultivators of the Arfak Tribe who have local wisdom values, namely Igya Ser Hanjob who experienced a shift in cultivation patterns caused by population pressure, oil palm plantations, family gardens, plantations of other clans, transmigrants and infrastructure expansion ((Ataribaba et al., 2020).

Among the tribes whose lives depend on nature (forests) is the Semende tribe. Semende tribe in history are shifting cultivators, but Semende tribe who live on Pulau Panggung, Tanggamus Regency, Lampung Province no longer live as shifting cultivators. This tribe survives in the customary forest bordering the damaged protected forest. Even in order to survive, the tribe, whose livelihood is from growing coffee, was forced into conflict with the New Order government, which adopted a policy of forest conservation by expelling people living in protected forests, arranging the boundaries of protected forests with customary lands so that the area of customary land was reduced because it was included in the protected forest area. protected forest (Mulyaningsih, 1997). Semende tribe also lost their non-formal authority in regulating forest use because since Law Number 5 of 1979 concerning Village Government, the headman has the authority to regulate people's lives.

In this condition, Semende tribe survives because it is supported by traditional wisdom called tunggu tubang. In contrast to most ethnic groups in Indonesia, tunggu tubang inheritance pattern is to give the first daughter the right to manage all family inheritance but to give her the obligation to take care of her parents and siblings until they are able to live independently. In managing the family's inheritance, tunggu tubang is obliged to occupy the heritage house, it is forbidden to sell the inheritance, marrying a fellow Semende tribe. Problems arise when these rules cannot be maintained due to the decrease in customary land, the marriage of the Semende tribe with other tribes who carry values about inheritance 
that are different from tunggu tubang pattern, changes in decision-making patterns in the family, job mobility from agriculture to non-agriculture, the more unprofitable agriculture. Also, the role of tunggu tubang is getting tougher because on the one hand it maintains traditional wisdom, and on the other hand there are modernization values that place women not having to be in the house to be farmers, but have the freedom to choose work, get education and choose a mate other than the Semende tribe.

Surprisingly, even though there was disharmony when there was a shift in the traditional wisdom of tunggu tubang (Gustar, 2019), there was an adaptation mechanism to change so that harmony returned. For example, when tunggu tubang does not carry out traditional obligations, disharmony arises, but becomes harmony when these obligations are represented by their parents; the emergence of a conceptualization in which control over tungguan is handed over to women (tunggu tubang), while control over property is handed over to men (jenang) (Arifin, 2020); there is also a change in local wisdom. Tunggu Tubang, which was originally in harmony with the surrounding natural environment, eventually undergone drastic changes (Murdiati et al., 2018); even many conflicts due tunggu tubang's property, which are resolved with family relations (Manangin et al., 2020).

So in the process of change, there is a shift in the traditional wisdom of waiting for tubang. However, this shift was responded to by innovations so that this traditional wisdom still survives. So the problem is how the innovations are carried out in maintaining the traditional wisdom of tubang from the aspects of Adaptation, Purpose, Integration, and Latent Maintenance.

\section{METHODS}

This study uses a descriptive quantitative method. The respondents are 40 respondents who were randomly selected from tunggu tubang. Research data were taken through interviews with respondents using a questionnaire. However, to complete the data, interviews were conducted with key informants, traditional figures, public figures and youth figures obtained using the snowball method. research analysis using Talcott Parson's functional structural theory. Whereas the traditional wisdom of Semende tribe continues to function along the four functional imperatives for the "action" system, that is the AGIL scheme, namely A (adaptation), G, (goal attainment), goal achievement, I (integration), L (latency) or pattern maintenance. The data obtained are arranged in frequency tables so that important information can be provided as a basis for drawing conclusions.

\section{RESULTS AND DISCUSSION \\ Custom of Semende Tribes}

Semende consists of two syllables: seme $=$ same and ende = price. This means that women do not buy, bachelors are not bought. In a marriage, it is interpreted that the man comes not for sale, the woman waits not to buy. In Semende's custom applies high inheritance and low inheritance, both of cannot be divided and the eldest daughter is appointed as guardian. 's women are only waiting for inheritance, are not allowed to sell, but are allowed to manage and take the output; men are in power but do not wait for 's wealth, let alone sell it. According to $\mathrm{H}$. Tjikdeham (in (Karnaen, 2020), men and women both benefit: 1) Women are defended, men defend, 2) Women are loved and men are pursued high education, learn the Koran until Mecca, 3) women quickly get married (Semende) so that parents have the opportunity to earn money to find school fees for the sons, learn the Koran and the costs of son's marriage, 4) both expect results, women can quickly start families so that their offspring develop, and men marry for another (semende).

The distribution of indigenous men and women of , has a special philosophy in elevating women as holders of traditional rights which are still intact. The elevation of woman is implemented in the form of the institution of marriage and inheritance. Besides that, Semendo tribe community has special symbols to strengthen the tradition of (Mahdi, 2019). However, (Anzani \& Sarwono, 2018), shows that gender-biased constructions in have been produced and reproduced through the spread of such beliefs since childhood and widespread domination in the social sphere. In addition, 's women see their position and role as destiny and cultural identity that they must accept. However, such perspective was not so broad among informants living in more developed areas because their lifestyle was more economically oriented and practical.

Semende tribe lives in the foundation of traditional wisdom called Tunggu Tubang . is the first daughter in Semende family to be granted inheritance rights to a house, rice field, garden and other immovable property. For this inheritance right, to be given the role of binding her extended family, fulfil family needs, take care for all people who live with her in 's house, such as parents and siblings who have not yet married until 's brother is married and can be independent. Thus the values contained in are the 
guardians of family resilience and the determinants of the future of the family, binding the family so that conflicts do not occur. The arrangement of inheriting only one daughter is also intended so that the area of rice fields or gardens is not divided into small parcels so that land management is maintained.

The custom of is a characteristic of Semende customs because it is different from other tribes of Pasemah family. The presence of in a clan is a must because they are the guarantor of the survival of Semende tribe. However, the position and role of is not permanent or immediate. There is a reason is dismissed or disilirkan.

1. Not obeying customary rules may be shifted or rotated to their younger sibling or other siblings and the related person who wants to sign the submission.

2. No longer live in the village, for example domiciled and doing business outside the region (city) or working outside the area by themselves that they will not live in the house and the house will be occupied by their parents along with their unmarried siblings.

3. Has come out of the house and set up a them selves. So the position of the first daughter as a, does not absolutely apply in the life of Semende society. When a family does not have a daughter, can be given to the son by making his wife to be through this process of appointment called ngukit marriage. A ngukit marriage is a son from the family who is married to a girl from a child from his father's or mother's relative. By carrying out a kawin ngukit, a woman enters the husband's family with the intention that she and her husband can take care of 's property which according to Semendo's custom area must continue to be held by the daughter. Although there appears to be discrimination and subordination of men and women, the function of harmony is still the goal of the customary arrangement of the. When 's women wait then sons are tasked with supervising the inheritance so that it is not damaged, diminished, lost. Men have no right to wait, but will become king reigns and be given the title Meraje. A meraje man from his mother's tribe becomes the people in his wife's tribe (Indra, 2019).

The custom of, grows in a matrilineal kinship system, or maternal lineage. As explained by LevyStrauss (in Anshori, 2019), kinship in society can arise because of blood relations, marital relations and hereditary relationships. The kinship system is kinship ties that serve as a means of binding certain individuals into social groups, such as families. According to (Koentjaraningrat, 1974), the principle of heredity in kinship relations applies to at least four types, namely the principle of partilinial (patrilineal descent); Matrilineal Principles; Bilinial principle (bilinial descent); Bilateral Principle (bilateral desecent) (Koentjaraningrat, 1974). According to (Morgan, 1877 in Carmichael \& Rijpma, 2017), the matrilineal system (mother's nisab) is the oldest kinship system in the history of human civilization. This system is followed by nisab-bapa system or patrilinial and finally a two-sided or bilateral kinship system. Generally, the kinship system in Semende society in South Sumatra is matrilineal, but some are not. It is called matrilineal because the (oldest) woman becomes the heir and guardian of the family heirloom. Muhammad Tairu (in Efrianto, 2017), Semendo community adheres to the principle of matrilineal kinship; as Minangkabau people. Meanwhile (Doty Darmayanti, (in Efrianto, 2017) states that it is not matrilineal because a child is part of the family of the father and mother. so that the role of the woman (the oldest child) is only as a bearer of the mandate to protect the inheritance for everyone.

Customary provisions, must live in the heirloom house so that it is not free to migrate outside the area like the sons. Because has to take care of their parents and younger siblings who are not married. is a substitute for the position and role of parents in caring for children. Besides, has to pay attention to the rules as follows: 1). Obliged to take care of their parents and younger siblings even though them, their husband and children are busy. 2). has to pay for the education of their siblings who are not married. 3) Cannot neglect their siblings. If they violate or neglect their obligations, they will be advised by jenang jurai. If they remain negligent, a family meeting is held to determine sanctions. Family meetings are attended by jenang jurai, payung jurai and meraje or people who are in the kinship system. The meeting was held to respond to 's negligence and the most fatal mistakes, namely selling inheritance. If they are just planning to sell, then jenang jurai or the oldest brother will advise them. If there is no change, to be tried in the family. If have sold the inheritance, then they are disobedient or meraib. Received moral punishment will make them leave the house or invite their husband to leave the house.

The values contained in are described by informants of young traditional leaders of Semende Tribe (interview with young leader Semende tribe name Irsi Jaya tanggal 21 Desember 2020); by (Subari \& Marshal, 2020);(Roryan et al., 2020), as kujur / Tombak / Balau, which reflects honesty; Kampak 
/ Kapak which means to act fairly in developing, protecting the family; jale or jala which means jurai is not divided and commanded by meraje; tebat or fish pond which means to remain patient even though there are problems; jars which means that semende people usually receive guests, either close or extended family. According to Semende's traditional figures, nets mean growing, needles are sharp for good, ax means not taking sides in making decisions, kujur or spear which means straight in action, jars are good at keeping disgrace. In line with these values, do not refuse the family to stay at their house. They have to welcome their family. Towards their family, do not behave rudely. As a substitute for their parents, the unifier of the family, and always upright in action; prohibited from abandoning siblings who are not married; are prohibited from selling family assets / tubang assets. Inheritance is a family property that can be taken but cannot be sold. It is even forbidden to pawn without the permission of jenang jurai (family deliberation). If there are family problems, it is not allowed to reveal family secrets.

\section{Semende Tribe Externalities: Peubah}

Pulau Panggung District where Semende tribe lives in Tanggamus Regency covers an area of $403.43 \mathrm{~km} 2$. In this sub-district stands Rindingan hill, which is a registered 32 protected forest area. In 2006 the condition of this hill was $84 \%$ damaged due to being turned into settlements, farming and coffee plantations ("Tutup Buku Di Pulau Panggung," 1990). According to the story of the past (Prijono, 2017), Rindingan Hill began to be visited by residents from Java Island in the 1950s. Way Harong Village, for example, was opened in 1948; Datar Lebuai in 1950, and Air Bakoman in 1953. The newcomers opened fields, planted coffee, cloves and pepper. By the end of the 1980s, coffee plantations had reached tens of thousands of hectares. The head of Gapoktan Sinar Baru Tumijo said, "I joined in 1982. At that time I was still single. At that time, this area had been opened by the first generation. And in 1988, Tumijo left the forest area of Register 32. "I left because there was an eviction from the government," recalled Tumijo. The expulsion operations on Register 32 went on in waves between 1988 and the 1990s. Police officers, soldiers, and Pulau Panggung Subdistrict government burned houses and planted coffee plants. (Now, parts of the old and new villages are covered in Air Naningan District.) The surviving residents were arrested by the authorities. Gradually, at least 300 heads of households who had lived in this register since 1958, were transferred to Rawajitu, North Lampung, and Perkebunan Inti Rakyat in Riau.
Hundreds of other families spread to the surrounding villages.

The population of Pulau Panggung District is the largest compared to other sub-districts $(26,500$ in 2020); however, the population in 2015 was 34,648 ; 1996 totaling 86,033 people (16,666 families). Although BPS recorded that the population growth rate was 1.19 , it was moderate, the population in the years before the 1998 reformation was very large. In this sub-district the Labor Force Participation Rate (TPAK) is very high at 67.3. This means that the drop out rate of school children after junior high school is very high. Although the Open Unemployment Rate (TPT) is only $5.3 \%$, the agricultural sector is very open to accommodating unemployed people. The percentage of poor people $9.8 \%$ is classified as low, and the HDI 71.4 is classified as good, as well as the life expectancy of $71.2 \%$ which is quite high.

The agricultural land in Pulau Panggung is getting narrower. As a research note, (Mulyaningsih, 1997) states that the area of Semende tribe coffee plantation in 1994 was 293,000 ha (Data from Pulau Panggung District Military Command), or 23,375 ha (1996 data from Kecamatan). In 2002 the area was only 10,978.5 ha, in 2020 there were only 7339 ha of coffee land. During this period, there was a Ministry of Forestry policy number 339/ Kpts-II / 90 regarding Boundary Arrangements. This policy is related to the government's interest in protecting protected forests. However, in this arrangement, the community was not involved so that many clan lands were included in protected forest areas. In a period of 24 years, there has been a change in land area due to the government policy to reforest protected forests with a boundary demarcation policy. The community complained about this boundary demarcation policy because it did not involve the community. Because as a result, the community lost part of its land area because it was included in a protected forest area (Mulyaningsih et al., 1997). In addition, the community also changed coffee plants to other crops, due to the dropping price of coffee. The transfer of land rights due to the inheritance process followed by the sale of rice fields and gardens also results in a decrease in land area. All three resulted in a kind of agricultural involution in Java. Namely the smaller the land due to the process of inheritance and land use change. This is the process that results in the shared of poverty.

The process of decreasing land area is accompanied by slow growth in the non-agricultural sector. Meanwhile, the coffee plantation sector, which is the mainstay of the Semende tribe, does not promise its selling price due to fluctuations in coffee prices. As an illustration, there are only SD (elementary 
school) in each village but only 1 Public Junior High School and 1 Private; 1 SMA (senior high school); 1 public health center; 1 supporting health center and 2 pharmacies; 6 general practitioners, 1 dentist. Population growth in Pulau Panggung is 1.19\% in 2020, medium category, Life Expectancy 71.2 which is classified as good. However, the Labor Force Participation Rate (TPAK) was 67.3 and the Open Unemployment Rate (TPT) was 5.3\%; percentage of poor people 9.8\%; IPM 71.4. Currently there are 18 ha of rice fields planted with vegetables and rice; There are 7,339 hectares of coffee plantations owned by 2267 households, so the average land ownership is 3.23 ha. Each hectare of coffee land produces $4,449,854$ / year (Incamilla et al., 2015). Coffee prices are very fluctuating, this makes it difficult for financial arrangements of . However, the actual number of households in Pulau Pnggung was 10,351 (in 2015) and 11,433 (in 2020). So that on average, the total land ownership is only 0.7 ha. The small area of this land has brought Semende tribe to low family resilience.

In this situation, Semende tribe still survives. The results of the interview show that the community still recognizes the meaning of . is a system of inheritance to girls that still known and implemented by Semende tribe community in Pulau Panggung. As regulated in custom, what is inherited are inheritance houses, rice fields, gardens and other immovable assets. This provision has been given since the first daughter was born. However, her rights were only granted after marriage. After marriage, obliged to live in an heirloom house to take care of the heirloom house, garden, rice fields, which the profit use to take care of parents, and the education of unmarried brothers and sisters until they are independent. If the first girl is incapacitated, then given to the next daughter. If there are no daughters so that there are no children (successors), a deliberation is carried out by Payung Jurai, Jenang Jurai and Ahli Jurai to determine the next because of a break in descent, it can be children of brothers and sisters siblings ( hasil wawancara dengan tokoh adat Semende (Muhadi, tanggal 21 Desember 2020; sesuai hasil penelitian (Resa Pahlawan's research, 2019).

\section{A Shift in the Traditional Wisdom of Semende Tribe}

The results showed that the majority of Semende tribe $(40 \%)$ have primary school education; have a junior high school education (32.5\%), high school education (17.5\%) and 10\% D1 / S1. Those aged more than 50 years were $62.5 \%$; $22.5 \%$ were aged 40-50 years, and those aged under 40 were $7.5 \%$. Some $(50 \%)$ are farmers on paddy fields and 's gardens, teachers, private employees, day laborers, some are migrant workers, traders (stall owners) and housewives. The marital relationship between Semende tribes is still strong, as it has been internalized through a process that goes down and down in the long run. Although based on research results there have been $10 \%$ marriage of with other tribes. Although inter-ethnic marriages are not prohibited, they also have nothing to do with education, employment, and decision making.

The shift in the traditional wisdom of Semende tribe will be seen in the aspect of 's right over inherited houses, gardens, rice fields, related to decision making as 's authority. (table 1)

Based on the custom of Semende tribe, is given the rights to houses, gardens and rice fields and therefore, is given the authority in making decisions in the management, utilization and distribution of inherited assets. In reality, now does not always get their rights. Only $30 \%$ cultivate houses, gardens, rice fields; there are $45 \%$ who get a house and garden; there are $2.5 \%$ who only get a house without a garden and rice fields; there are $10 \%$ only get gardens and rice fields; there are 5\% getting rice fields; there are even $7.5 \%$ who do not get a house, rice field and garden.

who has full rights over the house, garden, rice field has the authority to make decisions by $17.5 \%$, decision making on the husband by $10 \%$, and joint decision-making by $2.5 \%$. who has the right to house and garden, has decision-making authority of $15 \%, 27.5 \%$ of husband's decision-making, and $2.5 \%$ of collective decision-making. Some only get the right to a house, the decision-making pattern in 's family is carried out together. Next, get the right to garden and rice fields (without the house), the

Table 1. The Relationship Between Rights and Decision-Making Authority

\begin{tabular}{|c|c|c|c|c|c|c|c|}
\hline \multirow{2}{*}{$\begin{array}{c}\text { Decision-Making } \\
\text { Authority }\end{array}$} & \multicolumn{7}{|c|}{ Rights } \\
\hline & $\begin{array}{c}\text { House, Garden, } \\
\text { Rice Field }\end{array}$ & House, Garden & House & $\begin{array}{c}\text { Garden, Rice } \\
\text { Field } \\
\end{array}$ & Rice Field & Tepang Bangkang & Total \\
\hline & $17,5 \%$ & $15 \%$ & 0 & 0 & $2,5 \%$ & $5 \%$ & $40 \%$ \\
\hline Husband & $10 \%$ & $27,5 \%$ & 0 & $15 \%$ & $2,5 \%$ & $2,5 \%$ & $52,5 \%$ \\
\hline Joint & $2,5 \%$ & $2,5 \%$ & $2,5 \%$ & 0 & 0 & 0 & $7,5 \%$ \\
\hline Total & $30 \%$ & $45 \%$ & $2,5 \%$ & $10 \%$ & $5 \%$ & $7,5 \%$ & $100 \%$ \\
\hline
\end{tabular}


husband's decision-making (15\%); for who only received rice fields, decision making by was $2.5 \%$ and by the husband $2.5 \%$. Meanwhile, those who are disobedient make decisions by waiting $5 \%$ and by their husbands $2.5 \%$.

's rights in the inheritance of the garden, the rice fields have shifted that they do not get it at all. Although the number is small, that is $2.5 \%$, this shift has the potential to increase in percentage considering that other shifts have also occurred. In decisionmaking, the authority of in making decisions is increasingly displaced by decision-making by the husband. This shift occurred in all conditions where 's assets was a house, garden, rice field, the authority was still higher $(17.5 \%)$ than the husband $(10 \%)$; but when 's assets are only houses and gardens, 's authority $(15 \%)$ is lower than husbands $(27.5 \%)$; When 's assets are only gardens and rice fields, has no authority because they have been replaced by their husband (15\%). Some variants are the emergence of joint decision making $(2.5 \%)$ by and husband where the right of is in the form of a house, garden, rice field; Joint decision-making also occurs in a situation where rights are only granted in the form of a house and garden (2.5\%) and a house (2.5\%). However, there is a variant where the right of only rice fields, the decision making of $(2.5 \%)$ and the husband (2.5\%). In the "tepang bangkang" condition, still have the decision-making authority of $5 \%$ compared to the husband $(2.5 \%)$.

The shift in traditional wisdom of can also be seen from the rights of in relation to their obligations (Table 2).

The results showed that who obtained the rights to the house, garden and rice fields and who received the house and garden all took care of their parents (75\%). But they no longer take care of their brothers and sisters when their siblings already have their own homes. However, there are $25 \%$ with variants of the right of in the form of inheritance from gardens and rice fields, houses only, rice fields only, and those who do not get rights or tepang bangkang, they do not take care of their parents because they have died. so most said they would not sell 's assets (92.5\%), except because of need (7.5\%) said they were allowed to sell. According to the data, there are $92.5 \%$ of the compliance with tradition who have not sold 's assets, and 7.5\% have sold their houses and land. But in the records the one who sell it is 's parents. So when the time it must be inherited, the assets is no longer there. That's what happened to tepang bangkang.

There were $22.5 \%$ not occupying the heirloom house, because they were not given an inheritance in the form of a house so that they had their own house and joined their husband had canceled their customary obligations to accommodate the family in their house. However, because there are rice fields and gardens inherited to them, it became their obligation to pay for their siblings to continue their studies.

In fact, many conflicts arise in inheritance. The reason is that when determining the distribution of inheritancethere is nograntletter oranyotherletter, only verbally delivered by the parents. In addition, it does not go through deliberation until after the parents die, especially brothers who want to own the inheritance. tend to give in by handing over their inheritance to their brothers. As a result, family relationships become fractured. Many inherited conflicts are also brought to court, but due to the slow handling of the courts, the families are generally resolved again by deliberation. However, deliberations are rarely resolved and the difficulty is that the family is not willing to meet again, let alone a deliberation. If what is being fought over is a little bit, the woman finally gives up, then the

Table 2. Table of Shifting Traditional Wisdom in Acquiring Rights and Carrying Out Obligations.

\begin{tabular}{|c|c|c|c|c|c|c|c|}
\hline \multirow{3}{*}{ Rights } & \multicolumn{7}{|c|}{ Obligations } \\
\hline & \multicolumn{3}{|c|}{$\begin{array}{l}\text { Living in the heirloom house and taking } \\
\text { care of their parents }\end{array}$} & \multicolumn{4}{|c|}{ Taking care of heirlooms (gardens and rice fields) } \\
\hline & Taking care & Not taking care & Total & Taking care & Not taking care & Not selling & Sell \\
\hline $\begin{array}{l}\text { Inheritance House, Gardens, Rice } \\
\text { Fields }\end{array}$ & $30 \%$ & & $30 \%$ & $30 \%$ & 0 & $30 \%$ & 0 \\
\hline Inheritance House Gardens & $45 \%$ & & $45 \%$ & $45 \%$ & 0 & $45 \%$ & 0 \\
\hline Inheritance House, Rice Fields & 0 & 0 & 0 & 0 & 0 & 0 & 0 \\
\hline Inheritance Garden, Rice Fields & & $10 \%$ & $10 \%$ & $10 \%$ & 0 & $10 \%$ & 0 \\
\hline Inheritance House & & $2,5 \%$ & $2,5 \%$ & $2,5 \%$ & 0 & $2,5 \%$ & 0 \\
\hline Inheritance Rice Fields & & $5 \%$ & $5 \%$ & $5 \%$ & 0 & $5 \%$ & 0 \\
\hline Inheritance Garden & 0 & 0 & 0 & 0 & 0 & 0 & 0 \\
\hline Did not acquire any inheritance & & $7,5 \%$ & $7,5 \%$ & 0 & 3 & 0 & $7,5 \%$ \\
\hline TOTAL & $75 \%$ & $25 \%$ & $100 \%$ & $92,5 \%$ & $7,5 \%$ & $92,5 \%$ & $7,5 \%$ \\
\hline
\end{tabular}


men's reputation is labeled as a mechaib in the eyes of the community, which means taking what is not $100 \%$ of his property. The relationship between them turned bad, so there is a relationship of "rapat-rapat tempurung" which means even though it looks normal but is not as close as you should be.

According to Parson, the change in the traditional wisdom of, which does not occupy an heirloom house, is a form of adaptation to the fewer inheritance of. This adaptation is carried out because the inheritance is not enough to support 's family. In fact, the phenomenon of "tepang Bangkang" appears, meaning that nothing else / the inherited property is not enough to support the family. If tepang bangkang means that you don't get enough inheritance according to customs, then they have no obligation to take care of a large family except for children and wives and if they can take care of female in-laws if there is an inheritance such as a house and rice fields, if not then the only obligation is the children and their wives.

The tepang bangkang exists because there was sales made by parents or payung jurai, jenang jurai, meraje because their position should be advising that there are no violations. When the violation is committed by payung jurai, or jenang jurai or meraje, what happens is a fatal mistakes which will imitate. If have sold the inherited property, then they are disobedient or meraib. So, what if the perpetrators are payung jurai, jenang jurai or meraje.

This adaptation is carried out so that the function of 's main family remains. It should be considered to violate customary functions or obligations. But this violation was tolerated because of the need for work and following the husband. Moreover, communication and transportation technology is increasingly making distance and time more effective and efficient. There has been a family conflict because not living in the heirloom house, was considered not carrying out their obligations even though they have already obtained an inheritance. In the end, 's parents take care of their children. Some even agreed that the inheritance was sold to be distributed to the family; there is an inheritance that is sold by.

The shift in traditional wisdom in Semende tribe brings a shift in aspects of goal attainment. At this time, the younger generation of Semende tribe did not quite understand the philosophy of. However, they still obey the customs, in the sense that they do not question the dynamics that occur in 's assets. is the ideal of the inheritance process which is deemed necessary to be maintained even though in reality there is an adaptation to new values (prioritizing batih family). This means that the values of are not fully considered to be used to maintain the integrity of the inheritance, protect the family, maintain the family's future, maintain family food security. The demand for change of inheritance by was shown to those who began to divide the inheritance in the Islamic way and the country method. The method of dividing may be decided to each family. Even though it remains with a note that it cannot be sold.

There is something interesting, although there is an adaptation to the shift in the values of, but in this adaptation, the aspect of social integration is prioritized. Conflict was an action that Semende tribe avoided. Because Semende people feel that when they migrate anywhere they will return to the heirloom house. The attachment to this heirloom house keeps the strong social integration strong and maintains social wisdom. They closed the inheritance conflict into a hidden conflict which in Semende's language is "rapat-rapat tempurung". Because, one of the values of is not to open disgrace.

The traditional wisdom of Semende tribe has undergone a shift where the rights to wait for tubang have been violated which results in violating the obligation to wait for tubang. This violation was caused by economic needs that could not be fulfilled by tunggu tubang's inheritance. Moreover, there are changes in demands for welfare in accordance with increasingly modern conditions in terms of education, health, socio-economy. This demand is followed by tunggu tubang's social mobility by leaving traditions or customs, including taking education and working outside their place of residence. This phenomenon shows that economic needs have become a factor that makes custom not obeyed. In fact, the customary violation was carried out by payung jurai or someone who were supposed to guard tunggu tubang's inheritance. This condition raises conflicts in the community, between those who defend custom and those who tolerate it because of economic needs. So, there are some community actions that carry out the adaptation function by adjusting themselves even though they violate and cause conflict.

The conflicts that occurred show that social irregularity has emerged in Sememende's society. Following Parson's scheme, social regularity will last as long as the system continues to function. Because, the agreement that forms customs as the basis for social integration is assumed to be able to overcome differences so that the community is seen as a system that is functionally integrated in a balance. Therefore, society is a collection of social systems which are interconnected and interdependent. What Parson said was not all true as shown by the shift in the tradition of tunggu tubang. 
At this time, although many continue to study and work outside Pulau Panggung, the younger generation and children still speak Sumedo in their daily interactions. The integration of the Semende ethnic wisdom values pattern takes place in the phenomenon of change that occurs. 's values are still ideal values even though there are changes. to be maintained (Latency), this system will still survive. The changes that exist are the ability of the system to respond to changes so that the system is able to equip, maintain and improve itself both in the form of individual motivation and cultural patterns that create and sustain motivation.

\section{CONCLUSION}

One finding regarding the custom of waiting for the tunggu tubang which was initially confirmed to be maintained turned out to be changing. A number of families no longer bequeath houses, rice fields, gardens, to tunggu tubang. Economic needs have made the Semende tribe commit customary violations, namely selling the tunggu tubang property, not inheriting the tunggu tubang waiting property, so they don't occupy the tubang waiting house, and don't take care of their parents waiting for the tubang tubang. This customary violation is tolerated and covered up as if there was no conflict (shell meetings), because selling the waiting tubang property is a violation and conflict is a family disgrace. In Parson's framework, the shift in traditional wisdom is not the reality of action as a function of adaptation to globalization, but adaptation to economic needs. This can be seen in the function of achieving goals (goal attainment) which has not changed fundamentally; so that social integration (Integration) still persists. The traditional wisdom of the Semende tribe has experienced a slight shift in the variation of decision-making patterns and tolerance for the sale of waiting-tubang assets within the limits of meeting urgent needs.

\section{REFERENCES}

Abbas,I.(2013).Pappaseng :KearifanLokal Manusia Bugis Yang Terlupakan. Sosiohumaniora, 15(3), 272-284.

Amrizal \& Sumadi. (2018). Transformasi Desain Terompah Datuak Dalam KonteksPerubahan Sosio Kultural. Sosiohumaniora, 20(1), 57-64.

Anshori, I. (2019). Analisis Kritis Terhadap Anatomi Teori Strukturalisme Claude Levi-Strauss (Larangan Incest dalam Sistem Pernikahan dan Kekerabatan, serta Relevansinya dengan Pendidikan Islam). Halaqa: Islamic Education
Journal, 3(1), 1-6. https://doi.org/10.21070/ halaqa.v3i1.2127

Anzani, P.P. \& Sarwono, B. (2018). Social Construction of Women Holding the Position of Tunggu Tubang in South Sumatra. Jurnal Komunikasi Indonesia, VII(2), 162-173.

Aridiantari, P., Lasmawan, Wayan, I. \& Suastika, Nengah, I. (2020). Eksistensi Tradisi dan Budaya Masyarakat Bali Aga pada Era Globalisasi di Desa Trunyan. GANESHA CIVIC EDUCATIONAL JOURNAL, 2(2), 68-78. https://ejournal2.undiksha.ac.id/index. php/GANCEJ

Arifin, Z. (2020). Piil Pesenggiri: Politik Identitas Komunitas Lampung. Patanjala Jurnal Penelitian Sejarah Dan Budaya, 12(1), 69-85. https://doi.org/10.30959/patanjala.v12i1.591

Ataribaba, Y., Setiawan, I. \& Noor, T.I. (2020). Pola Pergeseran Nilai KearifanLokal Sistem Ladang Berpindah pada Masyarakat Arfak. MIMBAR AGRIBISNIS Jurnal Pemikiran Masyarakat Ilmia Berwawasan Agribisnis, 6(2), 812-832.

Ayatrohaedi. (2006). Kepribadian Budaya Bangsa (Local Genius). Pustaka Jaya.

Carmichael, S. \& Rijpma, A. (2017). Blood is thicker than water: Geography and the dispersal of family characteristics across the globe. CrossCultural Research, 51(2), 142-171. https:// doi.org/10.1177/1069397117691025

Efrianto, A. (2017). Struktur Masyarakat Semende di Kabupaten Ogan Komering Ulu Selatan. Jurnal Penelitian Sejarah Dan Budaya, 3(1), 618-635.

Gadeng, A.N., Maryani, E. \& Rohmat, D. (2018). The Value of Local Wisdom Smong in Tsunami Disaster Mitigation in Simeulue Regency, Aceh Province. IOP Conference Series: Earth and Environmental Science, 145(1), 39-48. https://doi.org/10.1088/1755$1315 / 145 / 1 / 012041$

Gustar, G. (2019). Perubahan Pola Pemanfaatan Harta Warisan" Tunggu Tubang”. http:// scholar.unand.ac.id/47034/

Hidayati, D. (2016). Memudarnya Nilai Kearifan Lokal Masyarakat Dalam Pengelolaan Sumber Daya Air. Jurnal Kependudukan Indonesia, 11(1), 39-48.

Incamilla, A., Arifin, B. \& Adia, N. (2015). Keberlanjutan Usahatani Komi Agroforestri 
di Kecamatan Pulau Panggung Kabupaten Tanggamus. JIIA, 3(3), 260-267.

Indra, S. (2019). Semende Dalam Sejarah. Muara Enim News, 1. https://muaraenimnews.com/ semende-dalam-sejarah/

Karnaen, Z. (2020). Sejarah Asal Muasal Semende. MuaraEnim News Tv. https:// muaraenimnews.com/sejarah-asal-muasalsemende-lengkap-beserta-adat-tungu-tubang/

Koentjaraningrat. (1974). Kebudayaan Mentalitet dan Pembangunan.

Mahdi, I. (2019). Konsep Gender pada Masyarakat Adat Suku Semendo Kabupaten Muara Enim (Studi Kasus Pada Adat Tunggu Tubang). Jurnal Hawa, 1(1), 127-154.

Manangin, M. S., Nurmala, L. D., \& Martam, N. K. (2020). Pengalihan Atas Harta Warisan Di Indonesia. DIH: Jurnal Ilmu Hukum, 16(2), 177-189.

Mariane, I. (2014). Kearifan Lokal Pengelolaan Hutan Adat (1st ed.). PT Rajagrafindo Persada.

Moita, S. (2017). Kearifan Lokal Masyarakat Etnis Tolaki Dalam Pengelolaan Sumbar Daya Pesisir Di Kecamatan Lolanggasumetto Kabupaten Konawe Provinsi Sultra. Jurnal Sosiologi Pendidikan Humanis, 2(1), 16-22.

Mulyaningsih, H. (1997). Perambah Hutan di Kecamatan Pulau Panggung, Lampung Selatan (Suatu Tinjauan Sosiologis Terhadap Suku Semende).

Mulyaningsih, H., Rahardjo, \& Soetrisno, L. (1997). Perambah Hutan di Kecamatan Pulau Panggung, Lampung Selatan, Tinjauan Sosiologis Suku Semende. PPS-UGM, 10(4A), 1-200.

Murdiati, E., Sriati, Alfitri, \& Taqwa, R. (2018). The Local Wisdom of Tunggu Tubang Culture in the Challenges of the Times (Study on Ethnical Semende District Muara Enim South Sumatera). E3S Web.of.Conferences 68, 02011 (2018). 1 St SRICOENV 2018, 1-8. https://doi.org/10.1051/e3sconf/201868020

Oktaviani, D., Puspasari, R., \& Prianto, E. (2016). Strengthening Of Local Wisdom As The Basis
Of Inland Fisheries Management In Sumatra. http://ejournal-balitbang.kkp.go.id/index.php/ jkpi

Pratiwi, C. (2016). Pengaruh Kearifan Lokal Masyarakat Adat Kampung Naga Terhadap Pengelolaan Hutan. In Makalah Kolokium. http://kpm.ipb.ac.id/karyailmiah/index.php/ kolokium/article/view/3230

Prijono, A. (2017). BERBAGI RUANG KELOLAKisah dan Pesan Hutan kemasyarakatan Tanggamus-Lampung.

Roryan, K., Herawan, S. \& Harijanto, A. (2020). Kedudukan Anak Tunggu Tubang Dalam Pembagian Warisan Menurut Hukum Adat Semende Di Desa Pajar Bulan Kecamatan Semende Darat Ulu Kabupaten Muara Enim. http://repository.unib.ac.id/20823/

Sari, I.P. \& Zuber, A. (2020). kearifan Lokal Dalam Membangun Ketahanan Pangan Petani. Journal of Deevelopment and Social Change, 3(2), 25-35.

Sartini. (2004). Menggali kearifan Lokal Nusantara Sebuah Kajian Filsafati. Jurnal Filsafat, 37(2), 111-120.

Subari, A.S. \& Marshal. (2020). Mengenal Lambang Adat Semende Muara Enim Kabar Muara Enim. Kabar Muara Enim. https:// kabarmuaraenim.com/2020/06/07/mengenallambang-adat-semende-muara-enim/

Tutup Buku di Pulau Panggung. (1990). Tempo.Co. https://majalah.tempo.co/read/nasional/17184/ tutup-buku-di-pulau-panggung

Vuspitasari, B.K., \& Ewid, A. (2020). Peran Kearifan Lokal Kuma Dalam Mendukung Ekonomi Keluarga Perempuan Banyadu. Sosiohumaniora, 22(1). https://doi. org/10.24198/sosiohumaniora.v22i1.24078

Wahyuni, A. T. \& Pinasti, V. I. S. (2018). Perubahan Tradisi Wiwitan dalam Era Modernisasi (Studi Pada Masyarakat Petani di Desa Balak, Kecamatan Cawas, Kabupaten Klaten). Jurnal Pendidikan Sosiologi, 7(3).

Widiana, F. \& Wikantiyoso, R. (2018). implementasi kearifan Lokal Dalam Strategi Pengembangan Wisata Pantai Sendang Biru Untuk Pelestarian Pulau Sempu. Local Wisdom, 10(1), 9-17. 